\title{
ANALYSIS OF DERIVATIONAL AND INFLECTIONAL MORPHEME IN SONG'S LYRICS OF ADELE ALBUM.
}

\author{
Evan Afrii ${ }^{1}$, Intan Maulina ${ }^{2}$ \\ Politeknik Ganesha Medan, Medan, Indonesia \\ University of Efarina, Pematang Siantar,Indonesia \\ evanafri@gmail.com
}

Submitted: $16 / 06 / 2021$

Accepted: 16/06/2021

Publication: 16/06/2021

\begin{abstract}
This research aims to find the derivative affixes and Inflection affixin "Song Adele Album". This study is a descriptive qualitative study. Researcher tries to find derived words, ending affixes and roots from words in Songs Adele Albums without using statistical calculations. In this study, the author used all words containing prefixes and suffixes as data. The data source is all parts of the word, which are the beginning of the song sung by Adele's album. The result of analyzing the data is that the derived affixes and affixes found in the song Adele album are -er, -en, -ing, -ly, -ment, -ness, -ness as suffixes, and the affixes are -d, -s, -ed, -ing, -es, -er, -est. From the conclusions of this study, the author suggests that in order to improve their vocabulary mastery, readers should apply derived words and affixes by decomposing words into roots and affixes, because they can get the structure of a word from a word, and also discover how words are constructed. By understanding the roots, readers can construct words themselves.
\end{abstract}

Keywords: affix, derivational, inflectional, derivatives, morpheme

\section{Introduction}

Language is an essential communication tool in human life. Therefore, we must be able to master the language and its elements, such as vocabulary, structure, etc. The language itself contains two aspects, namely form and meaning. Regarding meaning, the smallest unit of meaning in a language is the morpheme.

Morpheme is defined as the smallest meaningful unit in a language (Lim Kiat Boey, 1975: 37). Words are composed of morphemes. Morphemes that can exist meaningfully independently are called free morphemes, while morphemes such as -er and $-\mathrm{s}$ that cannot exist meaningfully independently are called bound morphemes. Bound morphemes must be attached to free morphemes. Bound morphemes are also called affixes, which can be divided into prefixes, infixes and suffixes. English has only two binding morphemes, namely prefix and suffix

There are not infixes in English. Bound morphemes are divided into two categories, namely derived morphemes and inflection morphemes. This article attempts to discuss derived morphemes. These morphemes are complex, so it is important to understand what derivative morphemes are.

The difference between the derivative form and the inflection form is difficult to explain in some languages. This is what Bybee (1985: 81) said in his book: "The most persistent and undefinable thing in morphology is the difference between derivative morphology and inflection 
morphology". It can be said, because both deal with morphemes that are usually affixes, whether they are prefixes or suffixes.

\section{Literature Review}

The research and evaluation of previous studies is particularly important and critical for selecting appropriate research topics or assisting in the study of painting (boote and beile 2005). Without first understanding the literature in this particular field, researchers cannot conduct a lot of research (fink 2010). A literature review is a systematic, clear, and repeatable method for identifying, evaluating, and synthesizing the current framework of completed and documented work produced by researchers, students, and practitioners.

According to the concept of morpheme words containing text content, cat and brief each express a meaning of unmarried. Other words, such as people and textbooks, will appear independently (some and one, text and books, how and forever) regardless of whether they contain the most important meaning unit. In addition, cats and quick also contain major units (cat and -s, short and -ly), but these words have only one meaning and can be used independently. Obviously, words do not always constitute the smallest meaningful device in language.

The smaller components are called morphemes. It insists that the set is the smallest and guarantees that the morphemes cannot be divided into smaller units, and a few definitions will apply to it (martin at kinson and pals, 1982). John Lyons pointed out that "the smallest unit of such grammatical analysis that can form a word is usually called a morpheme" (introduction theory Languages, 1986).

The meaningful element in the phrase is the morpheme (Edward, 2003). For example, true, unfaithful, no doubt, more true, honest, etc. The largest morpheme has lexical meaning, just like look kite and talk. The other represents grammatical categories or semantic concepts, such as past tense (-ed in look) or plural (-es kites) or comparative (-er in taller).

\section{Research Method}

This study used a descriptive qualitative study because it is a descriptive qualitative study. Moleong (1983:3) pointed out that qualitative research is the result of a study in which descriptive data is accessed in written or verbal form by observing people's behavior. In descriptive research, there are many qualitative research steps. Select research topics by reading morphemes and apply lyrics.

The research data is the object of research on the derived morphemes and inflectional morphemes of the lyrics in Adele's album. The derived affixes and inflection affixes studied are the formation of the derived affixes and inflection morphemes in Adele's lyrics. When analyzing the data, the author used the following description techniques: (1) Researchers read the lyrics of the song "Adele Album", and then find out the derivative words, inflections, and morphemes in the song "Adele Album" (2) Researchers also use the words in "Adele Album" The song script (3) encodes and analyzes the data.

\section{Results and Discussion}

The author puts forward the research results as follows. The author also attaches a table as a supplementary explanation of the results of this study.

\section{Derivational and Inflectional Morpheme}

Two derived morphemes and inflection morphemes were found in Adele Album. They are derived prefixes, derived suffixes and inflectional morphemes. They are shown in the 
following table:

Table 1

The Kinds of Derivational and Inflectional Morpheme

\begin{tabular}{|c|c|c|c|c|}
\hline No & $\begin{array}{c}\text { Form of Derivational } \\
\text { Morheme }\end{array}$ & Amount & $\begin{array}{l}\text { Number of } \\
\text { Data }\end{array}$ & $\begin{array}{c}\text { Percentage } \\
(\%)\end{array}$ \\
\hline 1 & Derivational Suffix & 14 & $\begin{array}{l}4,5,6,7,8,9,10, \\
11,12,13,14,15, \\
16 \text {, and } 17\end{array}$ & $30 \%$ \\
\hline 2 & Inflectional & 33 & $\begin{array}{l}1,2,3,18,19,20, \\
21,22,23,24,25, \\
26,27,28,29,3 \\
0,31,32,33,34, \\
35,36,37,38,39, \\
40,41,42,43,4 \\
4,45,46,47\end{array}$ & $70 \%$ \\
\hline & Total & 47 & & $100 \%$ \\
\hline
\end{tabular}

According to the above table, the result of the types of derived morphemes and inflection morphemes is that there are $14(30 \%)$ data belonging to the derived suffix, and 30 (70\%) tree data belonging to the derived suffix. Therefore, the sum of all the data found in Adele Album is forty-seven data (100\%).

\section{The meaning of derived morphemes and inflection morphemes}

The meaning of a derived morpheme is a bound morpheme, which derives (creates) new words by changing the meaning or part of speech or both. Inflectional morphemes never change the syntactic category of the word or morpheme to which they are attached.

Example analysis of deriving prefixes and suffixes from sentences:

Table 2

The Meaning of Derivational

\begin{tabular}{|l|l|l|}
\hline Suffix & Meaning & Example \\
\hline -er & Does of & Filler \\
\hline -er & Does of & Meaner \\
\hline
\end{tabular}


IJEAL (International Journal of English and Applied Linguistics)

Volume : 99 | Number 99 | Month Year |E-ISSN : 9999-999x | DOI: doi.org/ijeal.v1n1.983

\begin{tabular}{|l|l|l|}
\hline -ment & Condition of & Pavement \\
\hline -ment & Condition of & Government \\
\hline -ness & State of being & Bitterness \\
\hline -ness & $\begin{array}{l}\text { Formed a noun expressing } \\
\text { state of someone. }\end{array}$ & Happiness \\
\hline -ing & $\begin{array}{l}\text { In the process of doing } \\
\text { whatever . }\end{array}$ & $\begin{array}{l}\text { Feelings, } \\
\text { trying, } \\
\text { mentioning, } \\
\text { missing, and } \\
\text { bursting. }\end{array}$ \\
\hline- ly & $\begin{array}{l}\text { Means of complete } \\
\text { something. }\end{array}$ & \begin{tabular}{l} 
Finally \\
\hline
\end{tabular}
\end{tabular}

The example of the process and the meaning of inflectional morphemex from the sentence analyzed:

Table 3

The Meaning of Inflectional

a. Verbal Suffixes Meaning

\begin{tabular}{|lll|}
\hline Suffix & \multicolumn{1}{c|}{ Meaning } & Example \\
\hline -s & $3^{\text {rd }}$ person, singular, present. & You who makes \\
-ing & Progressive aspect & I'm taking these chnaces \\
& (denoting action in progress). & \\
-ed & Past tense & I've tried my hardest \\
& & \\
\hline
\end{tabular}

b. Noun Suffixes

\begin{tabular}{|ccc|}
\hline Suffix & Meaning & Example \\
\hline$-\mathrm{s}$ & Noun plural matter & hands \\
\hline
\end{tabular}

c. Adjective Suffixes

\begin{tabular}{|cll|}
\hline Suffix & Meaning & Example \\
\hline -er & Comparative adjective/adverb & crazier \\
-est & Superlative adjective/adverb & darkest \\
\hline
\end{tabular}




\section{Conclussion}

Among the 47 data found in Adele Album, there are two kinds of morphology. They are derived morphemes and inflection morphemes. It is found in the data that Adele Album derived morphemes consist of derived suffixes (14 data/30\%) and inflection morphemes (33 data/70\%). The meanings of derived morphemes and inflection morphemes are bound morphemes, which derive (create) new words by changing the meaning or part of speech or both. Inflectional morphemes will never change the syntactic category of the words or morphemes to which they are attached.

\section{Bibliography}

Carstairs-McCarthy, Andrew. 1992. Current Morphology. New York.

Bauer,Laurie. 1998. Introducing Linguistic Morphology. University Press.

Beard, Robert. 1995. Lexeme-Morpheme Base Morphology. Albany, N.Y. State University of New York Press.

Katamba, Francis.1993. Morphology. Modern linguistics series. New York: St. Martin's Press.

Bloomfield 1933. Language. New York: Holt.

Crystal, David. 1992. An Encyclopedia Dictionary of Language and Languages. Cowley Road, Oxford: Blackwell Publishers.

Srijono, Djoko. 2010. An Introductory Course of Linguistics. Surakarta: Muhammadiyah University Press.

Kusuma. 2011. A Study on the Compound Word National Column in The Jakarta Post Newspaper Published December 2010. University of Muhammadiyah Surakarta. Research Paper.

Miftahul. 2012. An Analysis of Sense Based Sentences in Lenka Album. University of Muhammadiyah Surakarta. Research Paper.

Katamba, Francis. 1994. English Word. Routhladge, London.

1993. Morphology, Morphology "Morpheme the Smallest Word of Meaning”. The Macmillan Press. United Kingdom.

Afifah. 2012. Word Formation Processes on Slang Words Used by Transexsual. University of Diponegoro Research Paper.

Christina. 2011. Word Formation Analysis on Slang Words in the Indonesia Teenager's Novel. Research Paper.

Verawati. 2011. The Word Formation Process and Domain Analysis of Slang in Anak Kos Dodol Kumat Lagi. Research Paper.

Maharani. 2014. An Analysis of Derivational Affixes In The Land of Five Towers Novel By A. Fuadi Translated By Angie Kilbani. University of Muria Kudus Research Paper. 
IJEAL (International Journal of English and Applied Linguistics)

Volume : 99 | Number 99| Month Year |E-ISSN : 9999-999x | DOI: doi.org/ijeal.v1n1.983

Moleong, Lexy J. (2010). Metodologi Penelitian Kualitatif. Bandung: PT Remaja Rosdakarya Offset. 